This is a self-archived version of an original article. This version may differ from the original in pagination and typographic details.

Author(s): Lähdesmäki, Tuuli

Title: European Culture, History, and Heritage as Political Tools in the Rhetoric of the Finns Party

Year: 2020

Version: Accepted version (Final draft)

Copyright: (C) 2019 Routledge

Rights: In Copyright

Rights url: http://rightsstatements.org/page//nC/1.0/?language=en

Please cite the original version:

Lähdesmäki, T. (2020). European Culture, History, and Heritage as Political Tools in the Rhetoric of the Finns Party. In C. De Cesari, \& A. Kaya (Eds.), European Memory in Populism :

Representations of Self and Other. Routledge. https://doi.org/10.4324/9780429454813-10 


\title{
Chapter 9 European culture, history, and heritage as political tools in the rhetoric of the Finns Party
}

\begin{abstract}
Various studies have indicated how notions and (mis)interpretations of national history, heritage, and culture are utilized by diverse populist and extremist political parties in Europe. However, scholars have less explored how the idea of a common European history, heritage, and culture are used by these parties to justify their xenophobic, anti-immigration, anti-globalization, and monoculturalist political attitudes and the defense of 'us'. This chapter focuses on this question by examining the political rhetoric of the Finns Party, the core populist party in Finland. The data consists of selected texts discussing broadly the topics of the EU, Europe, nation, identity, and/or culture, published in the party newspaper between 2004 and 2017. The data is examined using critical discourse analysis by focusing on the notions and interpretations of a common European history, heritage, and culture as political tools in the party rhetoric. The analysis brings out how the texts in the party newspaper picture Europe as a cultural and value-based community sharing a common Christian heritage, traditions, and moral norms, particularly when a threat towards 'us' is experienced as coming from outside Europe's imagined geographical or cultural borders. The notions and interpretations of a common European history, heritage, and culture form a powerful tool of exclusion when they are perceived as a sphere of meanings that cannot be identified with without having generational or ethnic ties to it. Appeals to a common European history, heritage, and culture function as rhetorical mechanisms through which others can be discussed with a vocabulary that veils the prejudiced or discriminative connotations.
\end{abstract}


Chapter 9 European culture, history, and heritage as political tools in the rhetoric of the Finns Party Running Head Right-hand: Political tools of the Finns Party Running Head Left-hand: Tuuli Lähdesmäki

\title{
Chapter 9
}

\section{European culture, history, and heritage as political tools in the rhetoric of the Finns Party}

\author{
Tuuli Lähdesmäki
}

\section{Introduction}

Interpretations of the past are a common tool utilized in politics by all parties in the political spectrum. These interpretations - as well as misinterpretations - of the past have increasingly gained attention in Western countries along with the rise and establishment of diverse populist radical right movements and parties. Their ideological views and political agendas commonly focus on fostering and protecting 'the nation' as an ethno-cultural community, whose communality, unity, and originality are perceived as stemming from the past through chains of ancestry and intertwined ancestral and cultural inheritance. Thus, national history, culture, and heritage commonly form a cornerstone in populist radical right movements' and parties' 'politics of the past', that is, how the past is utilized for political purposes in the present.

Besides 'the national', various Western populist radical-right movements identify with a 'shared European history'. Several recent studies have noted how these movements utilize the effectiveness of 'the transnational' by highlighting certain historical events and their representation as icons that are repeated and circulated in their communication, particularly in social media. The battle of Vienna in 1683 as a victory over the Ottoman Empire in Europe (Bhatt, 2012; Feldman, 2012), the image of a medieval crusader as a defender of Western civilization (Schröder, 2017), and a Viking solder as a White Northern power (Teitelbaum, 2017) are examples of widely utilized imageries in the European 
Chapter 9 European culture, history, and heritage as political tools in the rhetoric of the Finns Party

populist radical right movements. They appeal across national borders and, thus, form a transnational layer of historical imagery among the populist radical right scene in Europe. The links between the nation as an ethno-cultural community and Europe as a transnational religious-cultural community have been recently emphasized particularly by the identitarian movements in Europe, such as the 'Generation Identity', whose anti-immigrant, racist, and xenophobic agendas (Vejvodová, 2014) are rhetorically veiled into a concern with the preservation of ancestors' ethno-cultural tradition and the cultural heritage characterizing the continent of Europe (Generation Identity, 2018).

Although the agendas of today's populism and radical right are multifacetedly linked with the past, this link appears to be an ambivalent asset, as Klandermans (2017) notes. Indeed, the legacy of the past that is used to empower populist radical right groups varies, not only in different countries, but also within different factions of these groups, and it changes along with temporal transformation of the political and social contexts in which these groups seek to increase their support. A rise from an alternative fringe movement into a parliamentary political party, as has happened to many of these groups in Europe, impacts how the past is used as their image-making instrument and political tool. For example, Teitelbaum (2017: 104) describes how the radical right party Sweden Democrats is publicly silent about fantasies of the Viking past while seeking to reach new supporters and has instead utilized folk culture, such folk music and dance, to soften their image.

Various studies on populist radical right parties have focused on examining how the idea of the nation and national culture are produced in their political rhetoric and action. How do these parties narrate and give meanings to the ideas of European culture, heritage, and history? How is 'the European' utilized as a tool in populist politics whose core interest is 'the national'? This chapter seeks to answer these questions by analysing the political discourse of one of the most politically successful populist parties in Europe, the Finns Party (Perussuomalaiset), which has managed to develop from a marginal political group into a key player in parliamentary politics, recently holding several core positions in the Finnish government. Through critical discourse analysis of selected articles from the party's newspaper Perussuomalainen, the chapter seeks to explore how the party's discourse and its relation to the past developed and transformed from 2004 to June 2017, when the party broke up into 
Chapter 9 European culture, history, and heritage as political tools in the rhetoric of the Finns Party

two parts. The radical faction took over power in the party congress, while the more moderate faction resigned and later founded a new party, the Blue Reform (Sininen tulevaisuus).

The chapter starts from a discussion on populism as a movement and rhetoric, and the intersecting core features of ideologies of the populist radical right. This theoretical section is followed by an introduction to the case party, a description of the selection and characteristics of the data, and a discussion of the analytical method. The analysis section brings forth the key findings discussed through several quotations from the data. The chapter ends with a discussion on the meanings of the findings and draws conclusions from the analysis.

\section{Populism as a movement and rhetoric and the ideological core of the populist radical right}

Rhetoric has a crucial role in populism (Laclau, 2005; Mouffe, 2013; Wodak, 2015). It constructs and mobilizes populist movements and parties and should be, thus, perceived as performative and functional. Populist rhetoric is often described as relying on an affective, emotive, and metaphoric language; polarization; simplification; stereotypification; vague expressions; perceiving threats, faults, and enemies (Bos and Brants, 2014; Laclau, 2005; Lähdesmäki, 2015); and appeals to 'cultural commonplaces' (Thévenot, 2011), meaning shared physical places or more abstract sentimental areas of cultural meanings that need no justification and cannot be rationalized. The 'discourse of people' forms the core of populism's rhetorical strategies (e.g. Hellström, 2006; Mudde, 2007). However, the notion of people in the discourse is profoundly flexible and can be used in various meanings, referring to 'men on the street'; people who live in the same state and form the nation; or more abstract 'us' who share common experiences, history, and culture (cf. Canovan, 1999: 5).

In all meanings, the 'discourse of people' in the rhetoric of populism either explicitly or implicitly constructs the idea of the nation. Mudde (2017) has emphasized nativism as one of the ideological cornerstones of populism. By nativism he (2017: 4) refers to 'an ideology that holds that states should be inhabited exclusively by members of the native group (the nation), and non-native (or 
Chapter 9 European culture, history, and heritage as political tools in the rhetoric of the Finns Party

alien) elements, whether persons or ideas, are fundamentally threatening to the homogeneous nationstate'. Nativism as an ideology combines nationalism and xenophobia and links and lays the groundwork for diverse discriminative attitudes and practices among European populist parties, such as White supremacism, welfare chauvinism, misogyny, and homophobia. Its emphasis on generational ties, ancestral roots, and 'blood lines' present the nation as a container, as a family to which one has access and belongs by birth (Norocel, 2013; Wodak, 2015: 76-77). In this ideology, the nation means a limited and sovereign community that exists and persists through time and is tied to a specific territory (space), inherently and essentially constructed through in/out opposition (Wodak, 2015: 76-77).

The populist radical right parties' objection to the EU and European integration stems from this nativist ideology. For these parties, the promotion of a pluralistic model of society and supra-national institutions and political actors in Europe represents an attempt to destroy nations and the 'natural' order of nationalism, and thereby a sense of belongingness and identity (Betz and Johnson, 2004). The ideologies of the populist radical right function in an intersection of diverse social, cultural, spatial, ethnic, racial, religious, and reproductive ties and interdependencies.

Laclau has theorized the discursive and performative nature of rhetoric in populism and its attempts at hegemony through the concepts of 'floating' and 'empty' signifiers. In his theory, 'floating signifiers' refer to elements that are particularly open to different ascriptions of meaning (Laclau, 2005: 133). 'Floating signifiers' have different connotations depending on the discourse in which they are used and, thus, they belong to an ongoing struggle between different discourses to fix the meaning of signs. 'Floating signifiers' are open to continual contestation and articulation to different political projects (Worsham and Olson, 1999: 1-2). An 'empty signifier' is simply 'a signifier without a signified' (Torfing, 1999: 301). Often becoming over-coded, 'empty signifiers' mean everything and nothing; they are emptied of any precise content (Torfing, 1999). For Laclau (2005: 133), these concepts are, however, closely connected.

Europe is a commonly recurring theme in the rhetoric of European populist parties. It is an idea and concept that can be represented as manifesting diverse unwanted phenomena, threats, and crises. However, it is also an idea that can include in populist rhetoric various positive connotations and 
Chapter 9 European culture, history, and heritage as political tools in the rhetoric of the Finns Party

appreciated values. Hellström (2006: 57) has seen the concept of Europe in populist political rhetoric as 'an "empty signifier" that lacks essence, since it is so over-coded with meaning that it signifies everything and nothing at the same time'. Lähdesmäki (2015: 84) has described Europe as a 'floating signifier', 'which can be filled with various meanings depending on the speaker's political aims. Their meanings are not only different in different political discourses, but they are also "floating" within a discourse.'

The 'floating' or 'empty' nature of signifiers can be used in populist rhetoric as a political tool to locate diverse faults outside the imagined 'us' and to project various threats and fears of 'others' on a common scapegoat. In European populist radical right rhetoric, the EU commonly functions as a scapegoat that can be blamed for various fundamental faults and threats, such as shaking the foundations of identity, culture, and heritage in Europe (Lähdesmäki, 2015: 83).

\section{The Finns Party newspaper Perussuomalainen as data, and method of analysis}

The Finns Party (Perussuomalaiset) was established in 1995 on the base of the disbanded Finnish Rural Party (Suomen maaseudun puolue). Since its establishment, the party has brought together a broad variety of social and political protests under its political umbrella. One of the major concerns of the party has been the EU and its integration politics. However, the level of Euroscepticism in the political discourse of the party and in the personal views of the party members has varied. The Finns Party can be characterized as nationalist-populist - both terms have been used in a positive way in the party programmes and the writings of longtime party chairman Timo Soini (Mickelsson, 2011). The national emphasis in the party strengthened and took a new direction in the end of the 2000s when nationalist views were increasingly combined with concerns about the impact of immigration on Finland and the development of multi- and intercultural societies in Europe.

In recent years, several scholars have identified at least two significant factions in the Finns Party: agrarian conservatives and a (radical) anti-immigration wing (Jungar, 2016; Pernaa et al., 2012: 
Chapter 9 European culture, history, and heritage as political tools in the rhetoric of the Finns Party

408-409; Ylä-Anttila and Ylä-Anttila, 2015). The older of these factions, represented by the former cadre of the Finnish Rural Party gathered around party chairman Timo Soini, combined moral conservatism and left-wing social and income distribution politics with strong populist antiestablishment appeals critical to the EU and the political consensus dominating Finnish political culture. The newer, decidedly right-wing faction focused particularly on opposing multiculturalism and immigration (Norocel et al., 2018). This faction got its inspiration particularly from blog postings of Jussi Halla-aho, who was selected to the Finnish Parliament in 2011 and to the European Parliament in 2014.

In fifteen years, the Finns Party grew from a political margin into a central player in the Finnish political sphere. It gained a major victory in the parliamentary elections in 2011 by receiving 19 percent of the vote. Polling close to 18 percent in the 2015 parliamentary elections, the party joined the central-right governmental coalition. The party succeeded to negotiate five ministerial positions in the government, including minister for foreign affairs (Timo Soini) and minister for European affairs, culture and sport (Sampo Terho). Governmental work and populism are, however, difficult to combine; by joining the government, a populist party merges with those to whom it objects and to whose politics it seeks to function as an alternative. This controversy blurred the political rhetoric of the Finns Party (Vaarakallio, 2017: 213-214) and led to a decrease in its support. The different factions of the Finns Party used to have fluid contours among the party members. However, in June 2017 the views of the factions escalated into a splitting of the party. The anti-immigrant right-wing faction took over the party, selecting Halla-aho as its new party chairman. Soini and over half of the Parliament Members of the party, including all the ministers, resigned and set up a new party.

Several scholars have analysed the political position of the Finns Party, particularly in comparison with other Nordic populist and/or radical right parties. While some scholars have emphasized its difference compared with other radical right parties, such as Sweden Democrats (Wiberg, 2011; Herkman, 2015), others have pointed out their similarities and juxtaposed it, for example, with the Sweden Democrats (Jungar, 2017; Jungar and Jupskås, 2014). The different views can be explained through the previous factions in the party and its transformation over the years. The 
Chapter 9 European culture, history, and heritage as political tools in the rhetoric of the Finns Party

anti-immigrant faction indeed has similarities with other radical right parties, but defining the whole party as such before its split is misleading (Palonen and Saresma, 2017: 37). Before the split, the party’s leadership, programme, and government policies cannot be perceived as radical right, as $\underline{\underline{\text { Mudde }}}$ (2017: 6) notes.

The Finns Party has an ambivalent relationship to cultural matters. While its political agenda and discourse emphasize both national and local cultures, the party has suggested cuts to cultural funding. The party's cultural programme, published for the 2011 parliamentary elections, included strongly disputed statements and suggestions, such as an objection to contemporary art:

The Finns Party perceives that its primary concern is to preserve the Finnish cultural heritage in contrast to supporting contemporary postmodern art. State funds for supporting culture have to be steered in a way that they strengthen the Finnish identity. It would be wise to leave economic responsibility for arty postmodern experiments to individual actors and the market.

\section{(The Finns Party Program, 2011: 10)}

The party's explicit emphasis on national cultural heritage and identity seeks to appeal to voters' national sentiments by simultaneously objecting to cultural forms easily claimed as elitist, such as contemporary art (discussed with the concept of postmodern in the party programme). This reference to postmodern art got a lot of critical attention in the Finnish media after the launch of the programme. As a result of this criticism, some of the core party members, including Soini, downplayed the meaning of the reference by claiming it as a joke or as an intentional 'hook' in the programme aimed at raising media attention (

Through emphasis on the 'national' and with strengthening anti-immigrant views, the concept of culture has become more and more value-loaded and politically charged in the political discourse of the Finns Party. 'National' is often intertwined in this discourse with religious references brought forth by several party members. Christian metaphors and references to the Bible are particularly common in the rhetoric of Soini, who is a devoted Catholic (Parkkinen, 2017). Moreover, 'national' in the 
Chapter 9 European culture, history, and heritage as political tools in the rhetoric of the Finns Party

discourse of the Finns Party functions as a contact point that ties together different cultural and social dimensions, as the following quotation from the party's cultural programme indicates:

Certain distinctive features, such as language, customs, art, notion of justice, nature, myths, and beliefs, impact each nation's identity. These features are unique for each nation, and this is exactly what diversity and richness in the world is about.

Regardless of how strong the trend of internationalization might become, the significance of nationalities and national identity will never disappear.

\section{(The Finns Party Program, 2011: 8)}

To examine the Finns Party's discourse and its relation to the past and the 'European', the analysis focuses on the party newspaper Perussuomalainen. The data of this chapter consists of texts published in Perussuomalainen between January 2004 and June 2017. The data collection took place in two phases: first, the texts were searched with the headwords the EU, Europe, nation, identity, and/or culture; and second, after a pre-read of the texts found, 732 of them were selected as the data because they contained more frequent uses or a deeper discussion about the headwords. 2 The data includes texts written in various genres. Their authors are typically Parliament Members of the Finns Party, key members in the party organization and the local sections of the party, and regular editors of the party newspaper. The data also includes opinion pieces written by party members and supporters. Although Perussuomalainen functions as an arena for building political communality within the party, it also enables communication of its agendas and aims to non-members.

The articles published in Perussuomalainen focus on the party's core areas of interest: economics, social politics, and criticism of the EU. The newspaper has also increasingly published texts on immigration and refugees. Texts that primarily discuss culture, history, or heritage are rare. However, texts that primarily focus on socio-economic issues may still include short, secondary, or implicit references to culture, history, and heritage through which diverse socio-economic issues are contextualized and given meanings - and politics related to these issues are motivated and justified. 
Chapter 9 European culture, history, and heritage as political tools in the rhetoric of the Finns Party

Thus, references to culture, history, and heritage, however modest they might be, participate in the formation of the political discourse of the party.

To scrutinize the discourse on culture, history, and heritage and their entanglement with the notion of Europe in the rhetoric of the Finns Party, the chapter utilizes critical discourse analysis in the examination of the data. With this method, the analysis seeks to trace the connections between microlevel linguistic expressions and macro-level socio-cultural structures to understand their mutual interaction and interdependence. By relying on a dialectical-relational approach within critical discourse analysis (Fairclough, 2009), the analysis treats the meanings of linguistic expressions and representations as not only 'local' or situational, but as social processes dialectically related to others. This approach emphasizes how each micro-level expression participates in the production and reproduction of the macro-level social-cultural structures and practices. Similarly, the macro level forms the framework in which the micro-level expressions are able to take place (Fairclough, 1995: $35)$.

Laclau and Mouffe have defined discourse as an attempt to fix a web of meanings. This attempt involves structuring of signifiers into certain meanings in order to exclude other meanings (Laclau and Mouffe, 2011). Fixing a web of meanings is an exercise of power seeking to gain hegemony. Thus, critical discourse analysis can be understood as an examination of the reproduction and reformation of a wider social world and the hegemony of practices within it. In practice, the analysis of the data took place through careful reading and re-reading of the data and examining first how the ideas and notions of culture, history, heritage, and Europe were entangled at the linguistic micro level and then what kinds of hierarchical structures, ideologies, positions, and exercise of power this entanglement produces.

\section{Discourses of the entanglement of Europe, culture, history, and heritage}


Chapter 9 European culture, history, and heritage as political tools in the rhetoric of the Finns Party

The Finns Party's ambivalent relation to Europe (Lähdesmäki, 2015, 2017) is manifested in Perussuomalainen through the ambiguity of the notions of European culture, history, and heritage used in its political rhetoric. This ambiguity can be explained with divergent patterns that Vasilopoulou (2017) has identified from the radical right opposition to European integration. All these patterns rejecting, conditional, and compromising Euroscepticism - are in favor of a cultural definition of Europe, meaning acceptance of common cultural, historical, and religious European characteristics and the common heritage of European peoples. Conditional and compromising patterns also support principles of cooperation in Europe. While compromising aspects still support certain European policy practices, all are against future EU polity (Vasilopoulou, 2017).

These patterns can be found in Perussuomalainen, in which the discussion on the EU and Europe brings forth the different factions within the Finns Party. Despite the general Euroscepticism, texts written by or reporting the views of party members representing the agrarian-conservative faction emphasize the importance of cooperation with and within the EU. In this discourse, the 'Union is not only a fortress of evil', as it creates 'dialogue between European nations' (Perussuomalainen [later PS]11/2013: 12) and it "cannot be taken as a mere fortress of darkness, as it has enabled European cooperation, for example in trade and solving environmental problems' (PS 12/2013: 11), as articles introducing the views of Sampo Terho, a Member of the European Parliament, and Pirkko RuohonenLerner, a leader of the parliamentary group of the Finns Party, explicate. ${ }^{3}$

Vasilopoulou (2017) notes how the radical right's cultural definition of Europe stems from a tripod composed of ancient Greek democracy, Roman legal tradition, and Christianity, creating at the same time a spatial definition of Europe. In the data, this tripod was a few times explicitly explained as the bases of Europe's culture and civilization. These elements were, however, commonly emphasized separately in the texts - and in a less highbrow manner.

The cultural definition of Europe in Perussuomalainen is actually much more complex than the tripod described by Vasilopoulou. In Perussuomalainen, Europe is a floating signifier whose meaning transforms depending on the political situation in which it is used. Therefore, also the entanglement of Europe, culture, history, and heritage is not static or stable but a flexible 'web of meanings' in which 
Chapter 9 European culture, history, and heritage as political tools in the rhetoric of the Finns Party

new discursive links and ideological connections are constantly in the making. While some texts in the data stress the legacy of democracy, law and order, and Christian belief and traditions in Europe, others include in the cultural definition of Europe ethnic and moral meanings and thus produce Europe as an ethno-cultural or cultural-moral entity. When this 'web of meanings' is combined with nativist ideology, it may lead, for example, to naturalization of the idea of monocultural nation-states or to (cultural) racism, emphasizing a tie between cultural and ancestral roots, the ethnic origin of Europeans, and, thus, Whiteness. In the following subsections, the entanglement of Europe, history, culture, and heritage is explored through four discourses that were identified in the analysis of the data.

\section{Naturalization of a Europe of nation-states}

'Nation' is a core entity that is used in the political rhetoric of the Finns Party to argue and justify diverse political attempts. In this rhetoric, 'nation' binds together the ideas of sharing the common national past, heritage, and ethnicity with the idea of the political sovereignty of a nation-state. Nationalism and nativism naturalize concrete and symbolic borders and cultural differences between nations. Moreover, the linkage between nation, nation-state, and political sovereignty defines in the data the idea of a 'real' democracy. This 'web of meanings' is crystallized in the following extract from Soini's column:"

It is necessary here to repeat the principle of national sovereignty, which is the cornerstone of democracy. National sovereignty means that only and exclusively such a people that forms its own nation, distinct from other nations, has an eternal and unlimited right to always and freely decide on all its own issues.

(PS 3/2010: 10)

In the extract, the idea of a nation as a distinct unit and a political entity is explained in relation to time; it is eternal and, thus, static and unchanging. In this discourse, the idea of a nation can also be naturalized in other ways, such as by emphasizing biological and evolutionist reasons for boundaries 
Chapter 9 European culture, history, and heritage as political tools in the rhetoric of the Finns Party

between nations. In the following extract, Vesa Saarakkala, an assistant of Soini, defends the nationstate by claiming that in borderless societies people regress:

No one should be hated, but one's own local community and own nation-state create security for people and enable to them carry out in life also other things than just survival. In a borderless society people regress because there are no natural relationships of trust between people, but instead individuals have to be controlled and their behavior starts to be based on a stimulus-reaction type of activity, similar to animals.

(PS 15/2008: 8)

This kind of combined nationalist and nativist logic of a nation creates the basis for the Eurosceptic views of the party. While nation, cultural-ancestral roots, the bordered space of a nation, sovereignty, and democracy are closely intertwined in this discourse, the EU is perceived as a threat to this 'natural' entity. The EU is seen as an impossible construction (because it lacks a 'nation') and a threat to 'real' nation-states because of its attempts to establish a 'new nation-state' (Lähdesmäki, 2015). This threat is crystallized in the summary of the party programme published in Perussuomalainen:

The Finns Party thinks it is sheer madness to imagine that one nation could be formed, by force and with success, in multinational Europe. Since democracy is the power of the people, it seems that those who have accepted the Treaty of Lisbon are not supporters of the power of the people.

(PS 7/2009: 21)

Europe is perceived in this discourse as a multinational and, thus, a multicultural entity in which all nations represent their own coherent culture stemming from their national past. This kind of Europe is, however, perceived in the discourse as threatened by the EU's integration process and the 'multicultural mingle' leaking over the borders of Europe, as a town councillor of Kotka, Freddy Van Wonterghem, notes: 
Chapter 9 European culture, history, and heritage as political tools in the rhetoric of the Finns Party

We want Europe to remain a patchwork in which independent states and nations are different both linguistically and culturally. We want to preserve the cultivated cultural heritage of Shakespeare, Sibelius, Mozart, Beethoven, Picasso, Michelangelo, and Rubens, which is threatened by the multicultural mingle - seasoned with American Cocacolazation - leaking over the borders. We support a Europe in which each nation can be proud of its national identity and traditions.

The Finns Party wants the diversity of Europe to remain for the forthcoming generations. In the long run, the EU elite wants to turn us into a gray European mass that wanders from one country to another. The main goal of this elite seems to be a monocultural Europe rather than the good old multicultural Europe.

(PS 5/2009: 5)

In the extract, cultural heritage is described with high cultural figures whose legacy is related to the 'good old Europe'. The figures who belong to the canon of European art and cultural history are used in the extract to promote the distinctness of national cultures in Europe. In the discourse of the data, Europe is, thus, naturalized as a 'Europe of nations' or rather a 'Europe of nation-states' - a bordered space of distinct ethnic nations demarcated by their national culture, heritage, and state-borders (Lähdesmäki, 2015, 2017).

\section{The past in the meaning-making of the $\mathrm{EU}$}

In the political discourse of the Finns Party, the EU and its political elite represent the key opponent of the people (and the party). In the data, the objection to this elite utilizes various references to the national past, the history of the EU, and twentieth-century political history in Europe. The power hierarchy between the European elite and the Finns is emphasized by calling this elite, for example, the 'lords of Brussels' or the 'lackeys of Brussels', who are represented as dominating or ignoring the poor and powerless common people. Due to this dominance 'the Finnish farmer, who used to be the master of his own land, has ended up as a crofter under the rule of the lords of Brussels' (PS 7/2009: 16), as Erkki Havansi, a candidate in the election for the European Parliament, states. This emphasis on the 
Chapter 9 European culture, history, and heritage as political tools in the rhetoric of the Finns Party

unfair power of the elite in the data puts Finland and Finns in the position of victim. The rhetoric that appeals to one's 'own land', its historical continuity, traditional life, and sense of justice is a means often used in the data to convince the readers of the moral legitimacy of the speaker and the party (Lähdesmäki, 2015).

The rhetoric of injustice also defines the narration of the history of the EU in the data. As Soini writes, 'Greece practically forced its way into the monetary union and Italy manipulated its financial figures. The EU started back then as an unholy alliance of German bankers and French socialists' (PS 1/2005: 8). Both the history and present day of the EU are described as a battleground of competing national interests, in which bigger and more powerful nations deprive the smaller nations in Europe's peripheries. The political attempts of these bigger nations are explained to reflect their national past, as Ahti Moilanen, the third chairman of the party, writes:

One farmer pondered why agricultural producers shouldn't be paid for the wood they sell. The answer can be found in the colonial background of France, Germany, and England. These countries have had to leave from their colonies with their tail between their legs, so now they practice exploitation in the peripheral areas of the EU!

(PS 4/2006: 15)

When other nations are perceived as threats to Finland and the sense of order and justice in Europe, they can be stereotypified in the data with cultural epithets, such as 'French wine farmers', 'Italian pasta manufacturers', and the Greek 'Zorbases'.

Hellström (2006: 182-183) has noted how 'Europe's other' is often searched for from outside its territorial borders, although it could be distinguished in time rather than space. In the pro-European discourses and official EU policy rhetoric, European integration is often justified by appealing to the prevention of the recurrence of Europe's warlike history, particularly the horrors of World War II. In Perussuomalainen, history is also used as a warning example for contemporary Europe, but from a different point of view. In the texts, the EU and European integration are paralleled with the Soviet Union and its undemocratic decision-making and authoritarian and oppressive politics. The EU is 
Chapter 9 European culture, history, and heritage as political tools in the rhetoric of the Finns Party repeatedly referred to as 'the EU Kolkhoz', 'Kolkhoz of money', 'Kolkhoz ship', and 'Eurostoliitto' (combining the Finnish words for Europe and the Soviet Union, Neuvostoliitto). The pro-European politics of the Finnish government is described as contemporary Finlandization: 'We used to bow to Moscow with scabbed knees, today it's Brussels', as a letter to the editor states in the newspaper (PS 11/2007: 19). Besides Brussels, multiculturalism and Islam are perceived as new Moscows. 'The Finnish political elite is always lying prostrate in diverse directions. It used to be the Soviet Union, now it's Brussels and Mecca' (PS 7/2009: 9), the newspaper reports.

In the data, elements common to the EU and the Soviet Union are found in undemocratic decision-making, subordination of nation-states under the same union, economic crises, bureaucracy, and propagandist machinery (Lähdesmäki, 2015). Moreover, links are drawn between silencing of dissidents in the Soviet Union and restricting public expression of radical right (racist) views. As a town councillor of Oulu, Olli Immonen, writes:

Day by day the EU (i.e. Eurostoliitto) starts to remind us more of the Soviet Union, where persecution of dissidents and criminals of thought was a daily practice. In the Soviet Union, dissidents were shut away in mental hospitals. We will see if the EU follows the Soviet Union in this practice, also.

(PS 9/2010: 23)

In the last few years the references to the Soviet Union, however, diminished in the data. This change in the discourse reflects the rise of a new threat to the Finns Party's political agenda. It also manifests the change in the party's quest for hegemony. The discourse on 'a lesson learned from the Soviet Union' transformed into discourse on defending the nations and Europe from the threat of the 'nonEuropean'.

\section{Europe as a cultural-religious-moral entity}

The antagonist 'other' in the political discourse of the Finns Party varies flexibly and takes different forms depending on the political potential of the 'other' to increase the support of the party. Moreover, 
Chapter 9 European culture, history, and heritage as political tools in the rhetoric of the Finns Party

the different antagonist 'others' form in the discourse a complex web of meanings in which 'the others' are seen as connected or even allied. The increased migration and forced mobility to and in Europe in the 2010s influenced and transformed the discourse on the 'other' in Perussuomalainen. Besides the core antagonist of the party, the EU elite, the discourse started to more and more reflect various fears of 'non-European' cultural features, religions, and social and societal values perceived as leaking into and gaining ground in Europe. The culprit in the increase of this 'unfamiliar' element in Europe was commonly found in the integration politics of the EU and the pro-immigration-minded and 'overliberal' politics of the European left, as party board member in Espoo Simon Elo notes:

The Soviet Union's utopia collapsed under its own impossibility. The Left across Europe has taken the promotion of multiculturalism, the idea of an enriching coexistence of different cultures within a state, as its new goal. The cultural relativism that is dominating Europe has given a little finger to cultures whose values do not reflect the western sense of justice nor European values stemming from Christian ethics and the -philosophy of antiquity.

(PS 15/2009: 23)

As the extract illustrates, the threat of the 'other' produces in the discourse a sense of 'us' distinguished from the 'other'. In the data, 'us' commonly refers to the core populist unit, a common people, particularly when it is perceived as oppressed by the elite. When the antagonist 'other' is located in the EU, the 'us' is commonly narrated as a nation, the Finns. The identification of the non-European 'other' transforms the focus of the discourse. In that case the nationalist emphasis of the discourse extends beyond national borders and includes in 'us' an ambiguous community of Europeans. This community is explained as sharing various common elements in terms of culture, history, heritage, values, religion, and morality. In this discourse, multiculturalism thus refers to an encountering of European and non-European cultures, which are both perceived as forming their own essentialist and 'pure' entities. 
Chapter 9 European culture, history, and heritage as political tools in the rhetoric of the Finns Party

The discourse that produces Europeans as 'us' in the data commonly brings forth Christianity as the basis of common values, morality, and mentality in Europe. This emphasis was first triggered by the EU candidacy of Turkey, as the following quotation from Soini's column illustrates:

Contrary to my stand and proposal, the Finnish government participated in removing the reference to a Christian value basis from the new EU constitution. Was this in anticipation of Turkey's possible EU membership or was it just about disregarding Europe's core value basis? When talking about Turkey, we also need to talk about Islam and religion.

(PS 9/2005: 3)

The emphasis on the Christian value basis of Europe creates 'non-European' Islam as its antithesis. In the data, Islam is defined as a negation of Europe, representing not only an antithetic religion but also contrary cultural, mental, and moral norms - which in the rhetoric of the data are closely intertwined with religion. In these views, Islam and Europe (or the West) are seen as two coherent entities that have their 'own lands', their original spatial homes. Christianity and Islam are commonly culturalized, spatialized, and outlined as essentialist sources of behaviour and identity for the people within 'their' territories (Lähdesmäki, 2015).

\section{The fear of 'Islamization' and the defense of Europe's liberal heritage}

The populist construction of a boundary between the imagined democratic West/Europe and the antidemocratic Muslim 'other' has been broadly discussed in recent literature (e.g. Mulinari and Neergaard, 2012; Lähdesmäki and Saresma, 2016). This construction also takes place through visual imageries repeated and circulated in the media as illustrations accompanying texts and talks about the Muslim 'other' (e.g. Richardson and Wodak, 2009; Macdonald, 2006). In Perussuomalainen, articles dealing with immigration and refugees are also commonly illustrated with iconic images: women wearing burqas, aggressive armed Arab men, and migrating masses, thereby manifesting the 
Chapter 9 European culture, history, and heritage as political tools in the rhetoric of the Finns Party

unfamiliarity, difference, and fear of the Muslim 'other'. This fear produces in the data a discourse on Europe's 'Islamization' that is argued, for example, through demographic statistics and birth rates of 'Europeans' and 'non-Europeans'. This discourse stems from the fear of the 'other' and at the same time utilizes this fear as tool to create anxiety among Finns and, thus, increase the support of the party. The discourse on 'Islamization' in the data draws forth the Huntingtonian idea of a clash of cultures or civilizations, which is foreseen as eventually leading to 'the end of European culture and civilization' (PS 10/2007: 6), as the vice town councillor of Oulu and the leader of the local section of the party, Veli-Pekka Kortelainen, claims. The views on clashing civilizations are combined in the discourse with evolutionist notions on combating cultures and a cultural 'battle' in which the strongest wins, as well with the 'scientific' approach using statistics to indicate how this 'battle' is proceeding. This discourse reflects populism's partial shift from nationalism to 'civilizationism' that is driven by the notion of a civilizational threat from Islam, as Brubaker (2017) notes.

The fear of Islam in the data blurs the previous logic of the Finns Party's populist discourse. Framing Muslims as the antagonist 'other' of the party produces a new image of 'us'. In the political rhetoric of the data, this new antagonism is manifested through a concern for and a promotion of values and ideas that the party discourse has previously ignored, dismissed, deprecated, or even objected to. The discourse on 'Islamization' constructs the party as a defender of liberalism, freedom of speech, gender equality, women's and girls' rights, LGBT rights, tolerance, and even a 'right kind of' intercultural diversity, as 'Islam does not accept multiculturalism' (PS 12/2010: 23), as the title of the opinion piece by Anne Lempinen states.

By standing up for values and culture defined as Western/European, the radical populist right in the Western European countries has managed to promote itself as an uncompromising defender of Europe's liberal heritage (Betz and Johnson, 2004: 319). Indeed, recent studies have pinpointed how Western European populist radical right parties incorporate into their discourse and political agenda certain hegemonic elements of liberal politics, such as gender equality and LGBT rights, in order to gain broader hegemony in those societies (Norocel et al., 2018; $\underline{\text { Brubaker, 2017; }}$ Marzouki, McDonnell and Roy, 2016; Wekker, 2016; Lähdesmäki and Saresma, 2016). A similar tendency can be identified 
Chapter 9 European culture, history, and heritage as political tools in the rhetoric of the Finns Party

in Perussuomalainen in the last years of the data. As the immigration working group of the Finns Party states:

Europe, and particularly the Northern European welfare states with their generous social security systems, is a tempting target for immigrants who do not have skills needed in the labor market or who, due to religious or cultural reasons, do not want to adopt European notions, for example, of gender equality and freedom of expression that are important for integration.

(PS 1/2015: 3)

Besides the concern for 'European liberal values', the discourse on 'Islamization' includes a concern for Muslim women's and girls' rights, perceived as oppressed in patriarchic migrant communities. Mulinari and Neergaard (2012: 17) describe how this kind of 'caring self' is created in populist radical right discourse to support racist views legitimized with the 'worry' about others. They call this kind populist concern ‘caring racism’ (see also Lähdesmäki and Saresma, 2014).

The discourse on 'Islamization' in the data commonly culturalizes religions, both Islam and Christianity, and treats them in a nativist framework. Therefore, religion, culture, and moral values are perceived as forming a tight entity and representing generational continuity. This continuity is seen as nearly impossible to break, as 'deeply rooted culture-based customs cannot not be changed' (PS 67/2016: 12), as interviewee 'Ossi' notes in an article that deals with Muslims' attitudes towards gays. The notion of culture as a moral entity stemming from the past through generational ties emphasizes culture as a static and unchanging sphere of values. In this notion, people are seen as representatives of 'their' culture and heritage and thus also static and unable to transform. This notion is crystallized in Jari Pekka Vuorinen's opinion piece in which he writes:

It is easy to install a new operating system in a computer, but just try to do the same to a human who is a product of a foreign culture. Authorities, even with the help of the police, have now awoken to educate refugees and asylum seekers by telling these representatives of a foreign culture about women's rights in Finland, among other things. However, each culture includes in itself a firewall that is difficult to penetrate. 
Chapter 9 European culture, history, and heritage as political tools in the rhetoric of the Finns Party

When a culture is the result of hundreds or thousands of years, a week or even a decade is not enough for our own culture to gain a sufficient foothold in a foreign operating system.

(PS 8/2016: 5)

Vuorinen's view on culture as a 'firewall' reflects more generally the notions of culture in this discourse. Culture is not seen as an arena that enables and advances encountering and dialogue between individuals and groups with different cultural backgrounds. It is rather perceived as hindering the possibilities for communication and understanding between 'us' and the 'others'.

\section{Conclusions}

The analysis of the political discourse in Perussuomalainen indicates how language use and rhetoric are crucial tools in populism. Through them, populist parties are able to create a web of meanings that link together certain notions of culture, heritage, history, religion, values, morality, and Europe as a physical and mental space. Language is an efficient tool in the quest for hegemony and attempts to increase support for the party.

In the analysis of this web of meanings, four core discourses were identified. Stemming from populism's nationalist and nativist emphasis, the first core discourse in the data seeks to naturalize the idea of a Europe of nation-states, in which each nation has its 'own' national culture and heritage threatened particularly by the EU's integration politics and the EU elite as the 'other'. Second, the history of the EU forms in the data a topic that is discussed in reference to the Soviet Union, thereby constructing Europe's political history as the 'other'. Third, the nativist emphasis of populism is also extended to include all of Europe as a cultural-religious-moral entity. This entity is particularly constructed around the idea of Christianity as a definer of cultural behaviour, values, morality, and mentality in Europe in comparison with 'non-European' or 'foreign' 'other'. Fourth, the fear of 
Chapter 9 European culture, history, and heritage as political tools in the rhetoric of the Finns Party

'Islamization' and the Muslim 'other' produces in the data a discourse whose speakers present themselves as defenders of Europe's liberal values and liberal political heritage.

The meanings of Europe in the data can be described as 'floating', following Laclau's views on different roles of signifiers in populist rhetoric. In some texts of the data, Europe does not have any common culture or heritage, as only nations are defined as their 'natural containers'. In others, Europe is perceived as sharing a common culture and heritage. On one hand, these diverse views can be partly explained by the heterogeneity of the Finns Party. The party draws together different kinds of agents connected by dissatisfaction with the current policies and a fear of various threats. On other hand, the 'floating' nature of meanings can be used in the populist discourse as a political strategy to locate threats outside the imagined 'us' and to project fears of 'others' on scapegoats. Although the meanings of Europe vary in the political discourse of the party, their articulation has a common motive: to defend the common people against the threat formed by its antithetic and 'othered' opponents.

The analysis reveals how a nativist notion of culture can be extended from the idea of a nation to Europe as 'a native community'. The notions and interpretations of a common European culture, history, and heritage form a powerful tool of exclusion when they are perceived as a sphere of meanings that cannot be identified with without having ancestral roots and generational ties to it or ethnic origins in it. Indeed, populist claims commonly include xenophobic or racist notions, but their explicit expressions are often avoided, censored, or cleaned up in the official discourse of these parties. The discriminatory views can be rhetorically hidden under seemingly neutral utterances. For example, the populist rhetoric commonly refers to 'culture' instead of 'ethnicity' or 'immigration' instead of 'race' (cf. Balibar, 1991: 20). By using this kind of rhetorical mechanism, 'others' can be discussed in populist discourses with a vocabulary that veils the prejudiced or racist connotations (Lähdesmäki and Saresma, 2014, 2016). Appeals to 'European' culture, history, and heritage in the discourse of the Finns Party is an example of this rhetorical mechanism.

\section{Acknowledgements}


Chapter 9 European culture, history, and heritage as political tools in the rhetoric of the Finns Party

This work was supported by the Academy of Finland under Grant SA274295 (EUCHE) and Grant SA257130 (POPULISM).

\section{Notes}

\section{References}

Balibar, É. 1991. Is There a Neo-Racism? In É. Balibar \& I. Wallerstein (eds.), Race, Nation, Class: Ambiguous Identities, 17-28. London: Verso.

Betz, H.-G. \& C. Johnson. 2004. Against the Current-Stemming the Tide: The Nostalgic Ideology of the Contemporary Radical Populist Right. Journal of Political Ideologies, 9(3): 311-327.

Bhatt, C. 2012. The New Xenologies of Europe: Civil Tensions and Mythic Pasts. Journal of Civil Society, 8(3): 307-326.

Bos, L. \& K. Brants. 2014. Populist Rhetoric in Politics and Media: A Longitudinal Study of the Netherlands. European Journal of Communication, 29(6): 703-719.

Brubaker, R. 2017. Between Nationalism and Civilizationism: The European Populist Moment in Comparative Perspective. Ethnic and Racial Studies, 40(8): 1191-1226.

Canovan, M. 1999. Trust the People! Populism and Two the Faces of Democracy. Political Studies, 47(1): 2-16.

Fairclough, N. 1995. Critical Discourse Analysis: The Critical Study of Language. London: Longman. Fairclough, N. 2009. A Dialectical-Relational Approach to Critical Discourse Analysis in Social Research. In R. Wodak \& M. Meyer (eds.), Methods of Critical Discourse Analysis, 162-186. London: Sage.

Feldman, M. 2012. From Radical-Right Islamophobia to 'Cumulative Extremism': A Paper on the Shifting Focus of Hatred. Faith Matters. www.faith-matters.org/wpcontent/uploads/2012/10/islamophobia.pdf 


\section{Chapter 9 European culture, history, and heritage as political tools in the rhetoric of the Finns Party}

The Finns Party Program for Parliamentary Elections. 2011. Suomalaiselle sopivin. Perussuomalaiset r.p:n eduskuntavaaliohjelma. 25 February. www.perussuomalaiset.fi/wpcontent/uploads/2013/04/Perussuomalaisten_eduskuntavaaliohjelma_2011.pdf

Generation Identity. 2018. Who or What Is Generation Identity? 30 January. https://identitarianmovement.org/

Hellström, A. 2006. Bringing Europe Down to Earth. Lund: Lund University Press.

Herkman, J. 2015. The Life Cycle Model and Press Coverage of Nordic Populist Parties. Journalism Studies, 18(4): 430-448.

Jungar, A-C. 2017. Continuity and Convergence: Populism in Scandinavia. In P. Nedergaard \& A. Wivel (eds)., The Routledge Handbook of Scandinavian Politics, 147-160. London: Routledge.

Jungar, A.-C. 2016. From the Mainstream to the Margin? The Radicalisation of the True Finns. In T.

Akkerman, S. L. de Lange \& M. Rooduijn (eds.), Radical Right-Wing Populist Parties in Western Europe: Into the Mainstream? New York: Routledge.

Jungar, A.-C. \& A. R. Jupskås. 2014. Populist Radical Right Parties in the Nordic Region: A New and Distinct Party Family? Scandinavian Political Studies, 37: 215-238.

Klandermans, B. 2017. Extreme Right Activists: Recruitment and Experiences. In C. Mudde (ed.), The Populist Radical Right: A Reader, 238-257. London: Routledge.

Laclau, E. 2005. On Populist Reason. London: Verso.

Laclau, E. \& C. Mouffe. 2011. Hegemony and Socialist Strategy: Towards a Radical Democratic Politics. London: Verso.

Lähdesmäki, T. 2015. The Ambiguity of Europe and European Identity in Finnish Populist Political Discourse. Identities: Global Studies in Culture and Power, 22(1): 71-87.

Lähdesmäki, T. 2017. Perussuomalaisten Eurooppa. In E. Palonen \& T. Saresma (eds.), Jätkät \& jytkyt. Perussuomalaiset ja populismin retoriikka, 133-148. Tampere: Vastapaino.

Lähdesmäki, T. \& T. Saresma. 2014. Reframing Gender Equality in Finnish Online Discussion on Immigration: Populist Articulations of Religious Minorities and Marginalized Sexualities. NORA: Nordic Journal of Feminist and Gender Research, 22(4): 299-313. 


\section{Chapter 9 European culture, history, and heritage as political tools in the rhetoric of the Finns Party}

Lähdesmäki, T. \& T. Saresma. 2016. Emotive Strategies and Affective Tactics in 'Islam Night'. In M. J. Power, A. Haynes, E. Devereux \& A. Dillane (eds.), Public and Political Discourses of Migration, 57-71. London: Rowman \& Littlefield.

Macdonald, M. 2006. Muslim Women and the Veil: Problems of Image and Voice in Media Representations. Feminist Media Studies, 6(1): 7-23.

Marzouki, N., D. McDonnell, \& O. Roy (eds.). 2016. Saving the People: How Populists Hijack Religion. London: Hurst.

Mickelsson, R. 2011. Suomalaisten Nationalistipopulistien Ideologiat. In M. Wiberg (ed.), Populismi. Kriittinen arvio, 147-174. Helsinki: Edita.

Mouffe, C. 2013. Hegemony, Radical Democracy, and the Political. London, UK: Routledge.

Mudde, C. 2007. Populist Radical Right Parties in Europe. Cambridge: Cambridge University Press.

Mudde, C. 2017. Introduction to the Populist Radical Right. In C. Mudde (ed.), The Populist Radical Right: A Reader, 1-10. London: Routledge.

Mulinari, D. \& A. Neergaard. 2012. Violence, Racism, and the Political Arena: A Scandinavian Dilemma. NORA: Nordic Journal of Feminist and Gender Research, 20(1): 12-18.

Norocel, O. C. 2013. Our People: A Tight-Knit Family under the Same Protective Roof: A Critical Study of Gendered Conceptual Metaphors at Work in Radical Right Populism. Helsinki: University of Helsinki.

Norocel, O. C., T. Saresma, T. Lähdesmäki, \& M. Ruotsalainen. 2018. Right-Wing Populist Discursive Constructions of Nordic Masculinities. Journal of Men and Masculinities: 1-22. DOI: 10.1177/1097184X18780459.

Palonen, E. \& T. Saresma. 2017. Perussuomalaiset ja populistinen retoriikka. In E. Palonen \& T. Saresma (eds.), Jätkät \& jytkyt. Perussuomalaiset ja populismin retoriikka, 13-42. Tampere: Vastapaino.

Parkkinen, L. 2017. Timo Soini ja Kaanaan kieli - pelastuksen politiikkaa ja saarnapuhetta. In E. Palonen \& T. Saresma (eds.), Jätkät \& jytkyt. Perussuomalaiset ja populismin retoriikka, 273296. Tampere: Vastapaino. 


\section{Chapter 9 European culture, history, and heritage as political tools in the rhetoric of the Finns Party}

Pernaa, V., N. Hatakka, M. K. Niemi, V. Pitkänen, E. Railo, \& M. Välimäki. 2012. Median vaaliagenda ja jytky. In V. Pernaa \& E. Railo (eds.), Jytky. Eduskuntavaalien 2011 mediajulkisuus, 396-410. Turku: Kirja-Aurora.

Rantanen, M. 2011. Soini: Postmodernin taiteen paheksunta oli vaalikikka. Helsingin Sanomat. 12 December 2011. www.hs.fi/politiikka/art-2000002513794.html

Richardson, J. E. \& R. Wodak. 2009. The Impact of Visual Racism: Visual Arguments in Political Leaflets of Aurstrian and British Far-Right Parties. Controversia, 6(2): 45-77.

Schröder, S. 2017. Medieval Crusaders as Defenders of Civilization? Current Images of the Crusading Past within the Populist Movements. Paper presented in Conference Uses of the Past held 9-10 November, University of Jyväskylä, Finland.

Teitelbaum, B. R. 2017. Lions of the North: Sounds of the New Nordic Radical Nationalism. Oxford: Oxford University Press.

Thévenot, L. 2011. Power and Oppression from the Perspective of the Sociological Engagements: A Comparison with Bourdieu's and Dewey's Critical Approaches to Practical Activities. Irish Journal of Sociology, 19(1): 35-67.

Torfing, J. 1999. New Theories of Discourse: Laclau, Mouffe and Žižek. Oxford: Blackwell.

Vaarakallio, T. 2017. Perussuomalaisten kaksoispuhe. In E. Palonen \& T. Saresma (eds.), Jätkät \& jytkyt. Perussuomalaiset ja populismin retoriikka, 199-217. Tampere: Vastapaino.

Vasilopoulou, S. 2017. European Integration and the Radical Right: Three Patterns of Opposition. In C. Mudde (ed.), The Populist Radical Right: A Reader, 124-138. London: Routledge.

Vejvodová, P. 2014. The Identitarian Movement: Renewed Idea of Alternative Europe. Paper in ECPR General Conference, Glasgow, UK, 3-6 September. https://ecpr.eu/Filestore/PaperProposal/ff2ea4db-2b74-4479-8175-7e7e468608ba.pdf

Wekker, G. 2016. White Innocence: Paradoxes of Colonialism and Race. Durham: Duke University Press.

Wiberg, M. (ed.). 2011. Populismi - Kriittinen arvio. Helsinki: Edita.

Wodak, R. 2015. The Politics of Fear: What Right-Wing Populist Discourses Mean. London: Sage. 
Chapter 9 European culture, history, and heritage as political tools in the rhetoric of the Finns Party

Worsham, L. \& G. A. Olson. 1999. Hegemony and the Future of Democracy: Ernesto Laclau's Political Philosophy. Journal of Advanced Composition, 19(1): 1-34.

Ylä-Anttila, T. \& T. Ylä-Anttila. 2015. Exploiting the Discursive Opportunity of the Euro Crisis: The Rise of the Finns Party. In H. Kriesi \& T. Pappas (eds.), European Populism in the Shadow of the Great Recession, 57-71. Colchester: ECPR Press.

All quotations from the Finnish texts are translated by the author.

Part of the data has been previously used to analyse the notions of Europe in the Finns Party's political discourse (Lähdesmäki, 2015, 2017).

All persons in the data are introduced in the position that they held during the publication of each quoted text.

Soini's blog postings are regularly published as columns in Perussuomalainen. 